\section{Ariane Getting bigger and better}

THIS is yet another milestone-week for Ariane, the satellite launching system developed by European governments under the aegis of the European Space Agency (ESA). Tomorrow, 23 May, the second test-flight of the Ariane system will be carried out from the rocket base in French Guiana. Today, 22 May, the Council of the ESA is meeting to decide how the cost of the next three years' development, estimated at 175 million units of account (about $£ 115$ million) should be shared among member states.

The plan is to improve Ariane to carry payloads of $2,000-2,300 \mathrm{~kg}$, compared with the $1,750 \mathrm{~kg}$ capacity of the current launcher. The new systems will be capable of placing two $1,000 \mathrm{~kg}$ satellites into geostationary transfer orbit and so will fulfil most of the requirements of launching heavy telecommunications satellites.

The development is planned in two phases and Ariane II and III should be complete by 1983. Ariane II will be developed first to carry payloads of up to $1,950 \mathrm{~kg}$ by increasing the thrust of the first and second stage engines and the propellant mass of the third stage. Ariane III, with a payload of $2,300 \mathrm{~kg}$, will have two boosters fitted to the first stage. The volume available for carrying satellites will be increased in Ariane III to allow two satellites to be launched together, reducing costs.

The stimulus for the Ariane programme has come from the Centre National d'Etudes Spatiales in France (France has funded $55 \%$ of the 790 million accounting units of the first phase of Ariane development over the past seven years). CNES has done much of the groundwork for Ariane II and III and is already planning later versions. According to $\mathbf{M}$ Bouillard, head of advanced projects at CNES, Ariane IV, which would be Ariane II with four extra boosters and a $35 \%$ increase in first stage development and would accommodate payloads of up to $3,500 \mathrm{~kg}$, could be developed by 1985 . Plans for Ariane V, however, are more ambitious. It would be capable of putting into orbit a manned vehicle which would return to earth under its own steam. CNES is also looking at the feasibility of recovering and re-using some components of Ariane $\mathrm{V}$. It hopes to develop Ariane V by 1990.

In the meantime, the development of Ariane I is coming to an end. Earlier this year ESA handed over routine production to a consortium of European industry, Arianespace. After the four test launches (the last is scheduled for early 1981) and two subsequent launches, ESA will be free

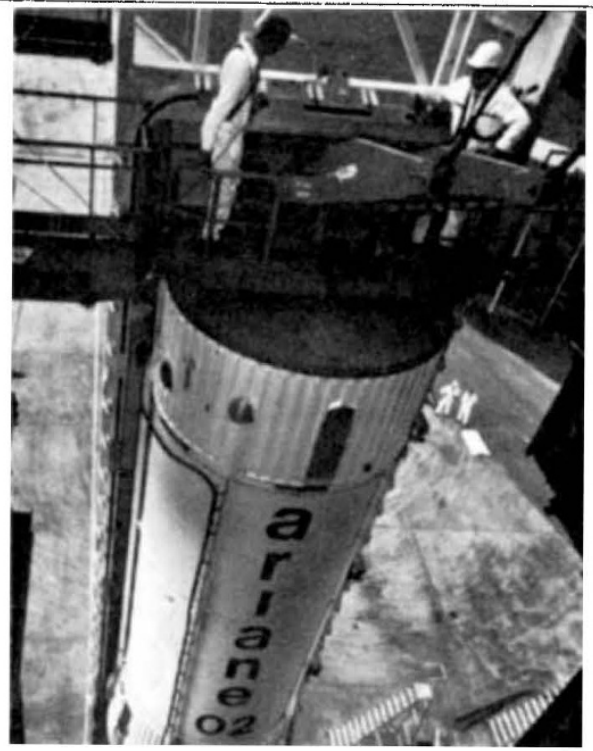

Ariane $I I$, second stage in the development of the ESA's satellite launcher, to be launched from French Guiana tomorrow.

of financial responsibility for further production, provided that Arianespace is financially viable. ESA member states are currently signing an undertaking to help bail Arianespace out should it ever get into trouble.

ESA will, however, retain responsibility for maintenance of the Ariane launch pad at Kourou, French Guiana. Member states will also decide at this week's council meeting whether to fund the building of a second pad at the site. The existing pad can handle only four launches a year. When the larger versions at the rocket come into operation, ESA estimates that up to six launches will be needed each year.

Even if, as expected, the plan for Ariane III is approved this week, the budget will be considerably less over the next three years than it was at the height of the development of Ariane 1. It is unlikely, however, that much of the money released will be channelled into ESA's other programmes, in particular the science programme, which desperately needs more funds. Any increase in the science budget, which is mandatory for all member states, would have to be approved by them all. Those who do not contribute to Ariane are unlikely to agree to spend more.

ESA's immediate concern, though, must be the success of the second Ariane testflight, scheduled for 23 May. The two small German satellites, "Firewheel" and "Oscar 9", carried free of charge, are also dependent on the success of the mission. "Firewheel" is a small satellite built by the Max Planck Gesellschaft to release barium and lithium clouds into the magnetosphere and monitor their movement through it. "Oscar 9" is a satellite for radio hams. If the flight goes as well as the first test, ESA and the German satellite operators should have few worries. Member governments may also pay up more cheerfully.

Judy Redfearn
Grant audits

\section{No easy riders}

\section{Washington}

THE dust is refusing to settle around conflicts between research universities and government accountants over the auditing of federally-supported research grants. It is more than a year since the Office of Management and Budget (OMB) issued the final version of its revised accounting rules, a document known as Circular A-21, hoping for a temporary pause in the skirmishing around grant accountability.

But complaints continue to mount, particularly over the requirement for detailed records of how scientists and technicians spend their time. The government's obvious interest is that funds allocated to a project should not be spent on anything else.

The suggestion is now gathering momentum that tensions may be resolved only by radical changes in the basis of research grants. One possibility is a shift from the "cost-reimbursement" basis to a fixed-price, grant-in-aid system, under which, once a grant has been awarded, research workers and their universities would decide how it should be spent.

Ample evidence of continuing frustration was voiced in Washington last week at a meeting of the advisory committee to the Director of the National Institutes of Health. It was plain that financial stringency has also exacerbated tensions between scientists and their universities.

The issue is the level of overhead costs universities should be entitled to add to research-grant proposals. Overhead percentages have increased rapidly in the past decade. The proportion of NIH granis spent on indirect costs rose from 28.5 per cent in 1970 to 41 per cent in 1979, according to a survey carried out by the National Eye Institute. On the grounds that when overall budgets are static, rising overheads mean less money for research proper, the council of the Eye Institute recommended last October that the NIH should reduce all indirect-cost allowances by a third. And the University of California's faculty Senate has rejected proposals from the University President for an increase in overhead percentages.

University administrators firmly resis! such reductions, insisting that indirect costs have increased dramatically, largely, they claim, because of federal regulations, for example covering affirmative action or occupational safety. They claim that most universities are able to collect only 80 per cent or less of the costs incurred in undertaking federal research commitments. At Washington University, according 10 Chancellor Dr. William Danforth, the total costs of carrying out federal research and training in 1978-79 was $\$ 49.6$ million, but only $\$ 40.4$ million was recovered from the government. 


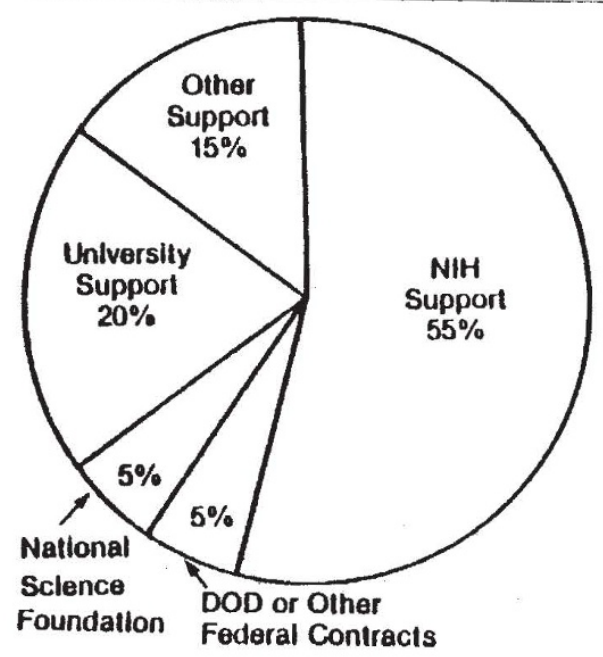

NIH estimate of the sources of income of a typical pre-clinical research laboratory in the United States (percentages of total).

More immediately troublesome for research workers is the need to give precise estimates of how much time they spend on projects.

Circular A-21 relaxed the time-andeffort demand by agreeing that faculty members need only complete such a record at the end of every term rather than every month (reports on technicians are still required monthly), and offering the alternative of "workload monitoring" where time allocation is agreed before a project is begun.

But research workers still find the system oppressive. Many claim it is unreasonable, for example, for a research scientist in a medical school to decide how time has been distributed between functions that may have been carried out simultaneously. "It is impossible to allocate one's time between research, training and patient care, and it is a sham to try to impose it," Dr David Kipnis, chairman of Washington University's School of Medicine, told last week's meeting.

Others argue about the difficulty of shifting from the rigours of scientific quantification to the "creative fictions" of the accountant. "We put a high degree of rigour on the numbers that we generate. So when we get a form asking us to put down numbers, we tend to think that they are the same type of numbers, ignoring the fact that they may not correspond to our notion of reality," said committee member Dr Howard Temin, professor of oncology at the University of Wisconsin.

Government auditors are unbowed. They insist that the revised A-21 requirements have considerably reduced the reporting load. They also point out that current auditing requirements follow directly from the way Congress has chosen to support biomedical research.

This has prompted increasing suggestions that alternative ways of supporting research should be explored. In a report on funding mechanisms soon to be published, for example, the National Commission on
Research (NCR) suggests that experiments be made with locally-managed grants-inaid, shifting the emphasis from detailed financial accountability to scientific accountability.

Under such a system, a grant proposal would still be closely scrutinised by the funding agency using the full peer review process. But once the money had been allocated, the investigators' prime responsibility to the agency would be to report on the technical aspects of the research. Administrative details would become the responsibility of the investigator and his or her university, with the funding system becoming the main incentive for the wise management of resources.

$\mathrm{NIH}$ is keen to encourage experiments along these lines for certain types of grants, according to director $\mathrm{Dr}$ Donald Fredrickson, while OMB officials say that, in principle, such a basis would be acceptable and simpler to administer.

In a different context, the National Science Board, the governing body of the National Science Foundation, has given some thought to the merits of block-grants to universities, so far without conclusion.

Not all universities relish the prospect of having to decide how a research worker is entitled to spend a federal grant. In addition to the increased administrative load, one result could be to translate current tensions between scientists and government accountants into the university setting. And there are several procedural issues, such as the way that indirect costs are calculated (currently as a proportion of the salaries and wages included in the grant) that would need to be revised.

The NCR, a body set up two years ago to examine all aspects of research funding, considers that these changes could work. But it urges the need for experiments. The National Science Foundation is already experimenting with post-award aggregation of grants to a selected number of university chemistry departments. The $\mathrm{NIH}$, which supports almost 50 per cent of federally-sponsored university research, is planning to follow suit.

David Dickson

\section{PWR design}

\section{UK programme gathers steam}

DESIGN work on modifying the Westinghouse pressurised water reactor system to meet British safety standards has begun "in earnest" following a letter of intent issued by the UK Central Electricity Generating Board to the Nuclear Power Corporation late last month.

The NPC is increasing the staff of its light water reactor team from 80 to 170 by the end of September, and plans a total of 400 by the end of 1982 . Design staff, who are not nuclear experts as such, are being recruited from engineering fields associated with complicated plant design including piping engineers, quality control draftsmen, power engineers and computer specialists. In addition the NPC is transferring part of its existing staff of 1,200 to PWR work. Included in this number are engineers from the advanced gas cooled reactors located in Hartlepool, Heysham and Dungeness. Two NPC engineers will fly to Pittsburgh next month to work with a Westinghouse licensing group on the transfer of the details of PWR technology to the UK. Five Westinghouse engineers will join the NPC team next month to work on modification of the Westinghouse design to meet UK standards. Technical support from Westinghouse will grow to about 100 professionals by 1982 .

NPC staff is concentrating its present efforts on computer simulations of safety procedures and on physical modelling of the layout of the $1100 \mathrm{MW}$ reactor. The design of steam, water, gas and cable runs is to conform with British safety procedures developed through experience in petrochemical plant design.

In conjunction with engineers from the CEGB, the NPC will prepare its modifications of the Westinghouse system which includes a novel "double skin" consisting of two concentric concrete cylinders with the reactor hardware in the inner cylinder and the safety and standby systems in the outer cylinder to meet operator radiation dose standards and plant standby power requirements, and to "relieve burden on the human element". The design work will cost $£ 3.5$ million.

The Nuclear Installations Inspectorate says that it expects to receive the CEGB's preliminary safety report - a general outline of the standard safety procedures to ensure reactor safety - within the next few months. This will be followed by a "steady flow" of design information beginning with a safety analysis of the main design followed by fault analyses of particular areas ranging from pressure vessel integrity and the possibility of fast fracture from small cracks (Nature, 28 February, p804) to the reliability of used equipment and component failure records. In spite of staff shortages, the NIl expects no difficulty in meeting its obligations to evaluate PWR safety.

Approval of the design modifications by the NII by 1982 will be followed by an application by the CEGB for a nuclear site license at the Magnox reactor site at Sizewell. At the same time, the promised public inquiry will also be announced and the safety documentation will be released in accordance with the government's announcement on 18 December 1979 that "principal safety documentation relevant to the initial licensing will be published and made available before the inquiry".

Jo Schwarte 